Article

\title{
An Economic Analysis of An Innovative Floating Offshore Wind Platform Built with Concrete: The SATH ${ }^{\circledR}$ Platform
}

\author{
Eugenio Baita-Saavedra ${ }^{1}$, David Cordal-Iglesias ${ }^{1}$, Almudena Filgueira-Vizoso ${ }^{2}{ }^{\mathbb{D}}$,

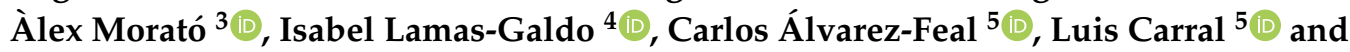 \\ Laura Castro-Santos $5, *$ (D) \\ 1 Escola Politécnica Superior, Universidade da Coruña, Esteiro, 15471 Ferrol, Spain; \\ eugenio.baita@udc.es (E.B.-S.); david.cordal@udc.es (D.C.-I.) \\ 2 Departamento de Química, Universidade da Coruña, Escola Politécnica Superior, Esteiro, 15471 Ferrol, \\ Spain; almudena.filgueira.vizoso@udc.es \\ 3 Saitec Offshore Technologies, Business Park Ibarrabarri, A-2 Building, Leioa, 48940 Bilbao, Spain; \\ alexmorato@saitec.es \\ 4 Departamento de Ciencias da Navegación e Enxeñaría Mariña, Universidade da Coruña, Escola Politécnica \\ Superior, Esteiro, 15471 Ferrol, Spain; isabel.lamas.galdo@udc.es \\ 5 Departamento de Enxeñaría Naval e Industrial, Universidade da Coruña, Escola Politécnica Superior, \\ Esteiro, 15471 Ferrol, Spain; carlos.alvarez@udc.es (C.Á.-F.); 1.carral@udc.es (L.C.) \\ * Correspondence: laura.castro.santos@udc.es
}

Received: 31 March 2020; Accepted: 23 May 2020; Published: 26 May 2020

\begin{abstract}
The goal of this work is to carry out an economic analysis of a novel floating offshore wind structure, of which the main material is concrete: the SATH ${ }^{\circledR}$ platform. It takes a step forward in floating marine wind energy research, in which traditional platforms are mainly composed of steel. The technique to calculate the costs of the platform and the economic parameters to decide if the farm is economically feasible are explained in the paper. This case study analyzes a possible farm of $500 \mathrm{MW}$ located in Portugal and several scenarios considering different electric tariffs and capital costs (Scenario 1: electric tariff of $50 € / \mathrm{MWh}$ and $6 \%$ of capital cost; Scenario 2: electric tariff of $50 € / \mathrm{MWh}$ and $8 \%$ of capital cost; Scenario 3: electric tariff of $150 € / \mathrm{MWh}$ and $6 \%$ of capital cost; Scenario 4: electric tariff of $150 € / M W h$ and $8 \%$ of capital cost). Results show the economic feasibility of a farm with the characteristics of Scenarios 3 and 4 . This work is significant in order to provide a new approach to analyzing traditional floating offshore wind structures, which can represent a path towards the future of floating offshore renewable energy technologies.
\end{abstract}

Keywords: IRR; SATH; concrete; floating offshore wind; LCOE; ocean renewable energy; NPV

\section{Introduction}

Due to the limits in fossil fuel reserves and the environmental problems caused by their combustion (since these are primarily responsible for greenhouse gases (GHG) $[1,2]$ ), numerous countries have made energy transition policies that highlight the need for less-polluting alternative energies, such as renewable energy.

In the Paris agreement [1], it was established as a priority objective to achieve a $20 \%$ reduction in greenhouse gases compared to 1990 and to increase to $80 \%$ in 2050 [3]. During the last few years, the European Union has developed significant methods to increase electricity generation using renewable resources. The fraction of renewable energies in the final electrical consumption increased from $8.5 \%$ in 2004 to $17 \%$ in 2016 [4]. 
Among renewable energies, one of the greatest possibilities is wind energy, representing $28 \%$ of the additional renewable capacity [5]. In 2018, at least twelve countries around the world achieved or exceeded $10 \%$ of their annual electricity consumption using wind resource.

In the offshore context, seven countries on the European continent and two on the Asian continent produced $4.5 \mathrm{GW}$, raising the cumulative global capacity by $24 \%$ to $23.1 \mathrm{GW}$. The success of offshore wind energy in Europe has generated interest in other regions. The future of wind energy will be focused on repowering onshore wind farms [6,7] or installing wind farms in offshore waters, where the wind resource is higher, but where there are other factors, such as areas where the farms cannot be installed (navigation areas, protected regions, etc.) [8].

Within the field of marine wind energy, it is important to show the evolution of this type of energy since $1991[9,10]$. In this year, the first offshore wind farm was built on the island of Lolland (Denmark). This offshore wind farm was named Vindeby Offshore Wind Farm [11] and was built by the Elkraft company (Lolland, Denmark), one of the predecessors of today's giant marine wind power company DONG Energy [12]. At that time, marine wind power was somewhat symbolic. The park was composed of 11 wind turbines with a power of $450 \mathrm{~kW}$ each, totaling $4.95 \mathrm{MW}$ of power.

From that moment, different technologies for the production of wind energy on the high seas began to be studied and their evolution through the years has been remarkable. It is expected that in the year 2030, $190 \mathrm{GW}$ of offshore wind will be installed [13].

There are two main types of structures for the use of marine wind energy: those that are fixed [14-16] to the seabed and floating structures. Fixed structures are designed for depths less than $50 \mathrm{~m}$ and floating structures for depths greater than $50 \mathrm{~m}$. Among the fixed structures we can talk about monopole, tripile, jacket, gravity structures. Within the floating structures we can talk about the Tension Leg Platform (TLP), spar, semi-submersible, TELWIND, SATH [17-20].

The SATH $^{\circledR}$ (Bilbao, Spain) concept means Swinging Around Twin Hull [21] and it is a new concept of floating offshore wind structure developed by the Spanish Saitec company (Bilbao, Spain). It is a semisubmersible concrete floating offshore wind structure. It has a Single Point Mooring system based on a structure that connects all moorings and the main electric cable to the same point in space.

The main advantages of the SATH ${ }^{\circledR}$ concept regarding other platforms are [21]:

- Total onshore construction.

- Use of high-durability concrete, reducing maintenance costs.

- Worthy scalability of the turbine size for mass production of large wind farms.

The main disadvantage of this new concept is that it needs time to be proven on the sea in order to increase its grade of development and produce it commercially.

One of the main problems of marine structures is the severe working conditions they are subjected to. Among these, marine corrosion occupies a very important role [22]. This causes the cost of these platforms to rise since the cost of maintenance is very high. As a result, their profitability decreases. That is why alternatives to these materials have been sought, and the exchange of steel for concrete in these structures is being studied. With this new material, the life of the structure is increased to 50 years and maintenance is reduced. Subsequently, the cost of the energy obtained is also lower and more competitive [23]. In addition, the weight of these new structures is different from the steel ones, which can make their installation easier.

There are different projects that have studied wind structures with concrete. Among them is WindCrete [24,25] (a project of the UPC-BarcelonaTech in Barcelona), TELWIND [19,26] (Esteyco company, Madrid, Spain) and SATH [27] (Saitec company, Bilbao, Spain).

The aim of this paper is to carry out an economic analysis of an innovative floating offshore wind platform whose main material is concrete: the $\mathrm{SATH}^{\circledR}$ platform. The floating offshore wind platforms analyzed in previous studies consider concepts built on steel (for instance: WindFloat, TLP or Hywind platforms); however, concrete can have some advantages when comparing its properties with steel. In addition, $\mathrm{SATH}^{\circledR}$ platform has an advantage to others in that the installation process 
is easier and cheaper than other platforms [21]. This paper will develop a method to calculate the costs of the platform and the economic parameters necessary to assess whether or not the farm is economically feasible. The case study will analyze a farm of $500 \mathrm{MW}$ located in Figueira da Foz (Portugal) and presents several alternatives depending on the electric tariff and the capital cost taken into account. Results show if a farm of these characteristics is economically feasible or not and presents the parameters its profitability depends on. The original contribution of this paper is to analyze economically this new type of concrete floating offshore wind platform, the SATH ${ }^{\circledR}$ concept, which can exemplify the future of the floating offshore wind industry in the world.

\section{Methods}

\subsection{Calculation of the Costs}

The method suggested for calculating the costs of the SATH ${ }^{\circledR}$ platform $\left(L C S_{S A T H}\right)$ is based on the costs of the life-cycle of the project considering all of its phases [28]: conception and definition $\left(C_{1}\right)$, design and development $\left(C_{2}\right)$, manufacturing $\left(C_{3}\right)$, installation $\left(C_{4}\right)$, exploitation $\left(C_{5}\right)$ and dismantling $\left(C_{6}\right)$ of the concrete floating wind farm, such as Equation (1) is shown [28].

$$
L C S_{S A T H}=C_{1}+C_{2}+C_{3}+C_{4}+C_{5}+C_{6}
$$

The investment of the farm is based on $C_{1}, C_{2}, C_{3}$ and $C_{4}$ costs in the first years of the construction of the platforms and the farms. $C_{5}$ is developing during all the years of the exploitation of the farm, when it has initiated its operational life. $C_{6}$ is considering only in the last year of the life of the farm (20 years in this study).

First, conception and definition cost depend on the cost of legal aspects $\left(C_{11}\right)$ and the cost of the previous studies (wind resource, the sea states and the seabed) $\left(C_{12}\right)$, as Equation (2) is shown [28].

$$
C_{1}=C_{11}+C_{12}
$$

Second, the design and development cost is based on the cost of the special purpose vehicle (SPV) $\operatorname{cost}\left(C_{21}\right)$, as Equation (3) is shown [28].

$$
C_{2}=C_{21}
$$

Third, the cost of manufacturing all the components of the farm depend on the wind turbine manufacturing $\operatorname{cost}\left(C_{31}\right)$, the SATH ${ }^{\circledR}$ platform manufacturing cost $\left(C_{32}\right)$, the mooring manufacturing $\operatorname{cost}\left(C_{33}\right)$, the anchoring manufacturing cost $\left(C_{34}\right)$ and the electric system manufacturing $\operatorname{cost}\left(C_{35}\right)$, as Equation (4) is shown [28].

$$
C_{3}=C_{31}+C_{32}+C_{33}+C_{34}+C_{35}
$$

On the other hand, the cost of installing the farm is composed of the costs of installing [29]: the wind turbine $\left(C_{41}\right)$, the $\mathrm{SATH}^{\circledR}$ platform $\left(C_{42}\right)$, the mooring and anchoring system $\left(C_{43}\right)$ and the electric system $\left(C_{44}\right)$, as Equation (5) is shown [28].

$$
C_{4}=C_{41}+C_{42}+C_{43}+C_{44}
$$

The exploitation cost is function of the assurance cost $\left(C_{51}\right)$, the administration and operations $\operatorname{cost}\left(C_{52}\right)$, the maintenance cost $\left(C_{53}\right)$, the onshore logistics costs $\left(C_{54}\right)$ and the offshore logistics cost $\left(C_{55}\right)$, as Equation (6) is shown [28].

$$
C_{5}=C_{51}+C_{52}+C_{53}+C_{54}+C_{55}
$$


Finally, the dismantling cost is dependent on the dismantling of each of the components of the farm; mainly, the wind turbine dismantling $\left(C_{61}\right)$, the SATH ${ }^{\circledR}$ platform dismantling $\left(C_{62}\right)$, the mooring and anchoring dismantling $\left(C_{63}\right)$ and the electric system dismantling $\left(C_{64}\right)$, as Equation (7) is shown [28].

$$
C_{6}=C_{61}+C_{62}+C_{63}+C_{64}
$$

\subsection{Installation}

The SATH ${ }^{\circledR}$ platform considers a pre-laid mooring system of six catenary lines in three groups of two lines oriented at $120^{\circ}$ to each other [20]. It considers a single point mooring, which makes an effective maritime system to handle anchors and lines of lower dimensions, which are less expensive [20]. For the installation of the mooring lines, an Anchor Handling Vessel (AHV) is required [20,30]. Anchors and chains are lifted by an onshore crane into the AHV deck area where they are fastened for the transport [20].

The installation of the electric cable (inter array and export cable) can be developed considering cable-laying vessels specialized in this type of work: load the cable manufacturer, storage in carousels, burial of the cable into seabed, etc.; This is because its installation is similar to other offshore wind turbines [20].

The installation of the SATH ${ }^{\circledR}$ platform is carried out using a main tug vessel that will tow the platform and two auxiliary tugboats that will assist the towing operation if necessary.

\subsection{Maintenance}

Regarding the maintenance process, $\mathrm{SATH}{ }^{\circledR}$ platform can offer a significative advantage with respect to other floating solutions, or even to the fixed ones, in case of big repairs (blades or other big equipment replacement) where singular maritime means such as jack-up rigs and floating cranes could be needed. Note that in high water depths or without enough seabed bearing capacity, jack-up vessels could be worthless. SATH ${ }^{\circledR}$ platform can be easily disconnected, towed to the nearest port and moored at the quayside where repairs could be done more easily and quickly with conventional and less expensive onshore means [27].

The routine of Operation and Maintenance (O\&M) activities for the wind turbine, tower and electrical equipment in floating platforms are similar to those of fixed offshore installations. Additional singular O\&M activities of floating technologies are mainly related to the mooring system, and the hull structure [27]. SATH ${ }^{\circledR}$ platform uses concrete, a material not requiring maintenance, in all parts of the platform that come in contact with sea water. Accordance levels of inspections have been established for the different systems integrating the platform and mooring.

\subsection{Calculation of the Economic Parameters}

The economic feasibility of a farm developed using SATH ${ }^{\circledR}$ platforms depends on the results of the following economic parameters: IRR (Internal Rate of Return), Net Present Value (NPV), DPBP (Discounted Pay-Back Period) and Levelized Cost of Energy (LCOE). The method of calculation is explained in Figure 1. 


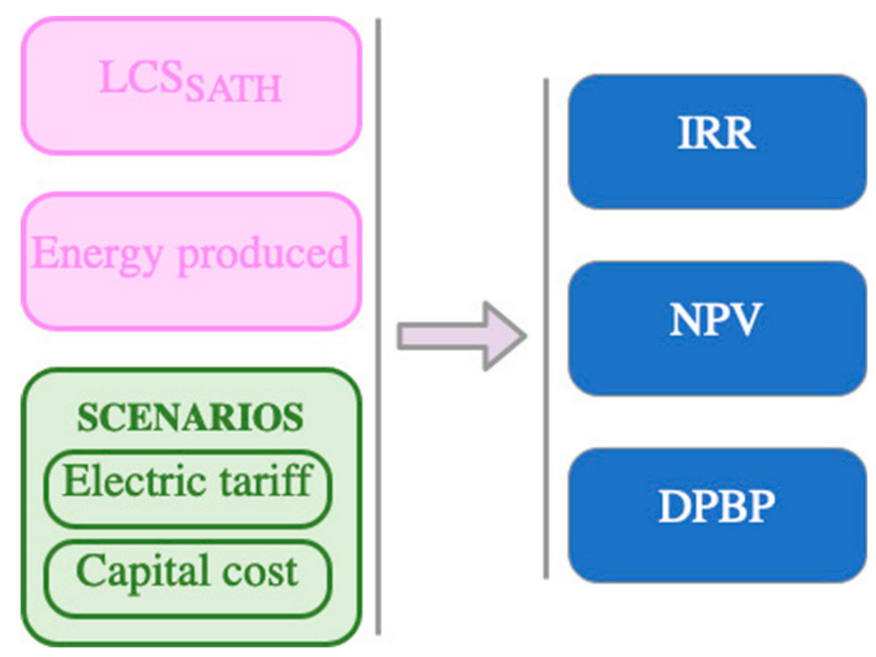

Figure 1. Calculation of the economic parameters.

\section{Case of Study}

The platform of analysis in this paper is the $\mathrm{SATH}^{\circledR}$ concept designed by the Spanish enterprise Saitec (see Figure 2).

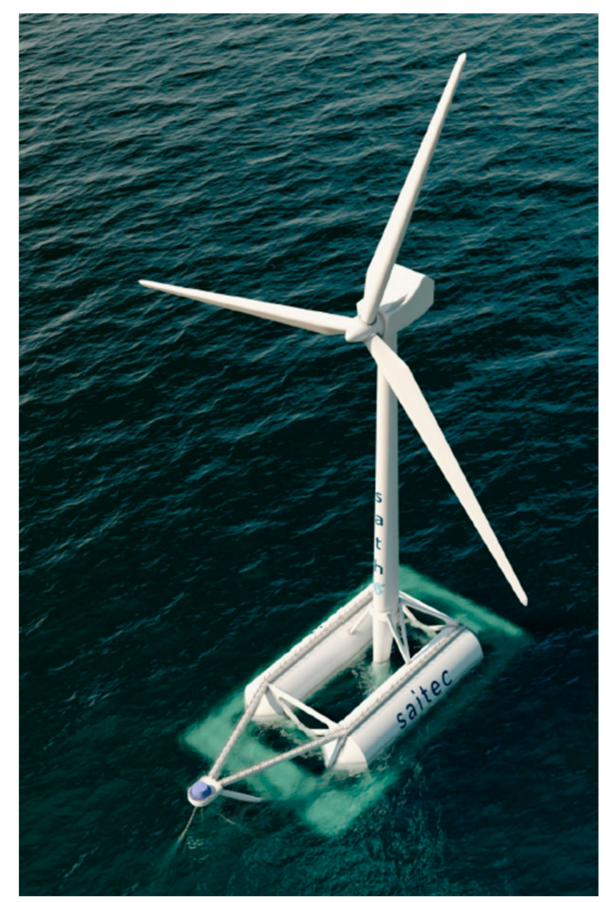

Figure 2. SATH ${ }^{\circledR}$ platform concept. Source: Figure courtesy of Saitec [31].

One of the main differences between the SATH ${ }^{\circledR}$ platform and the previous concepts of floating wind platforms is the composition of its hull, which is made of concrete instead of steel like previous platforms (WindFloat [32], TLP [17], Hywind [33]).

A prototype of the SATH platform, called BlueSATH ${ }^{\circledR}$ platform, will be installed in spring 2020 in front of the Sardinero beach in Santander, a city situated in the North of Spain, as part of the ARCWIND project. Figure 3 shows the construction of the BlueSATH ${ }^{\circledR}$ platform in the workshops. 

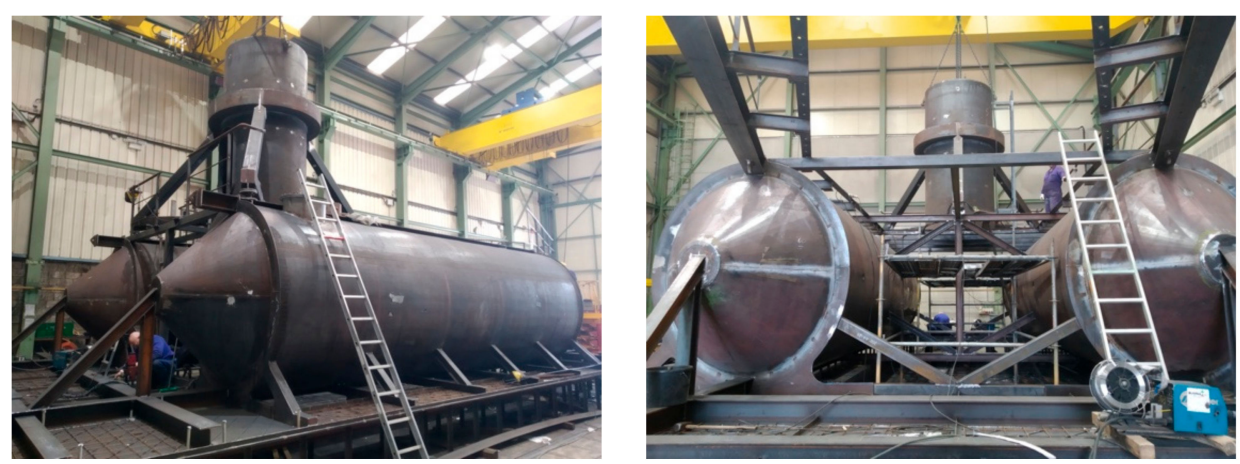

Figure 3. Building of the BlueSATH ${ }^{\circledR}$ platform in the workshops. Source: Figure courtesy of Saitec [31].

The technical data of the prototype concept are presented in Table 1 . BlueSATH ${ }^{\circledR}$ is the first offshore wind platform development of the Saitec company of a 1:6 scale prototype of a 10 MW wind turbine using the SATH ${ }^{\circledR}$ technology in open sea waters [31]. Its objective is to model the behaviour of SATH ${ }^{\circledR}$ concept, "allowing structural optimization, cost reduction and validating structural turbine integrity" [31]. It is composed of 3 chain moorings keeping their position using drag anchors [31].

Table 1. Technical data of the BlueSATH ${ }^{\circledR}$ platform [34].

\begin{tabular}{ccc}
\hline Concept & BlueSATH $^{\circledR}$ & SATH $^{\circledR}$ \\
\hline Type & Prototype & ARCWIND project \\
Wind turbine & AE-30 kW AEOLOS & DTU 10 MW \\
Power of the wind turbine & $30 \mathrm{~kW}$ & $10 \mathrm{MW}$ \\
Rotor diameter & $15 \mathrm{~m}$ & $178.3 \mathrm{~m}$ \\
Hub height (above MSL) & $17.6 \mathrm{~m}$ & $108 \mathrm{~m}$ \\
\hline
\end{tabular}

SATH ${ }^{\circledR}$ platform is composed of the following components (see Figure 4):

- Twin horizontal floaters stiffened with diaphragm walls with conical ends and linked with bar frames.

- Transition piece linking the tower to the platform.

- Heave plates linked to floaters.

- $\quad$ Single point mooring.

The location selected for the case of study, whose main characteristics are shown in Table 2, is Figueira da Foz (west coast of Portugal, Iberian Peninsula) [35,36] (see Figure 5).

Table 2. Location of the $\mathrm{SATH}{ }^{\circledR}$ platform [35].

\begin{tabular}{ccc}
\hline Concept & SATH ${ }^{\circledR}$ & Units \\
\hline Coordinates & $40.21 \mathrm{~N}-9.56 \mathrm{~W}$ & - \\
Bathymetry & 150 & $\mathrm{~m}$ \\
Distance from farm to shore & 51,000 & $\mathrm{~m}$ \\
Distance from farm to onshore facilities & 61,000 & $\mathrm{~m}$ \\
\hline
\end{tabular}




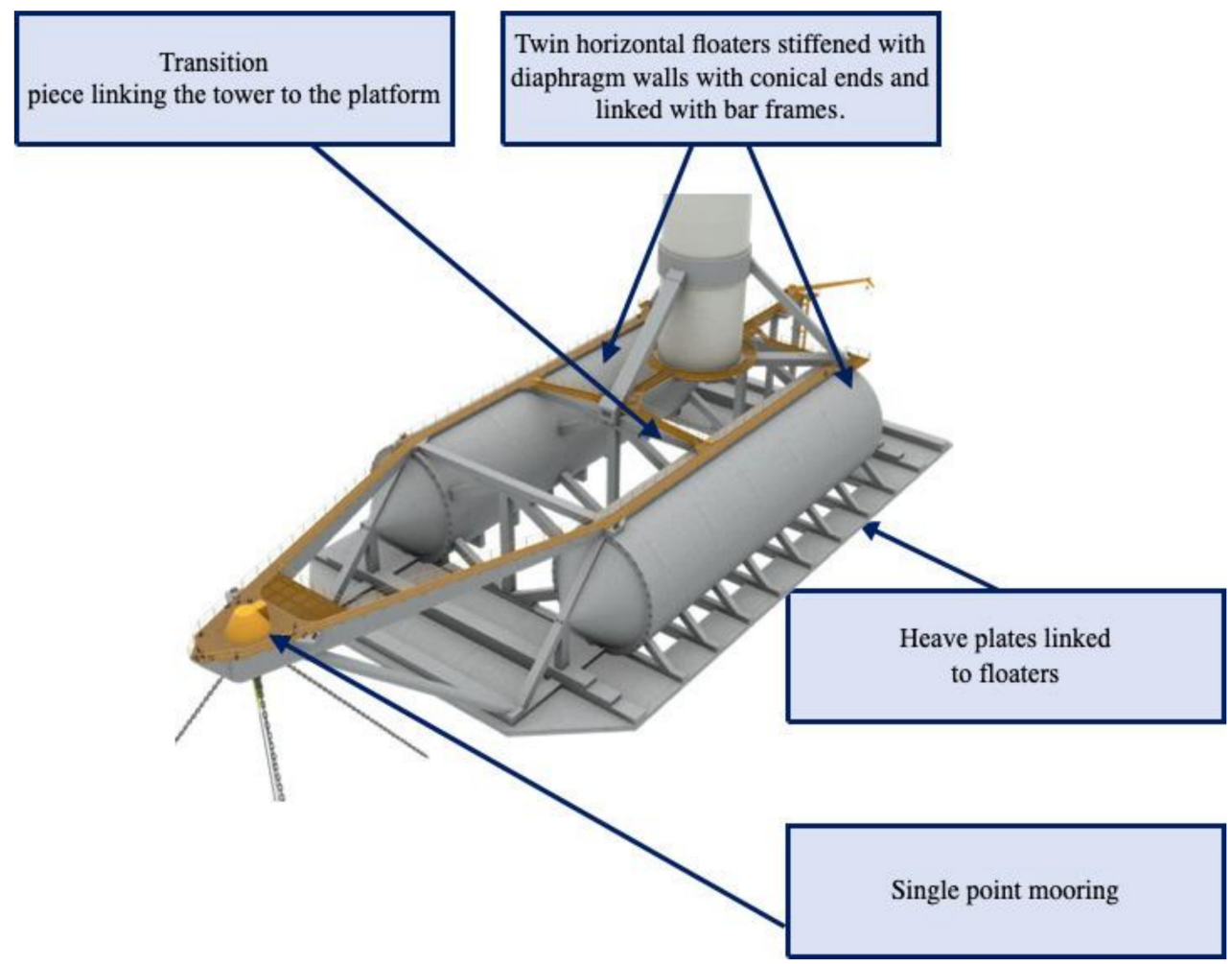

Figure 4. SATH ${ }^{\circledR}$ platform main components. Source: It has been adapted from a figure courtesy of Saitec [31].

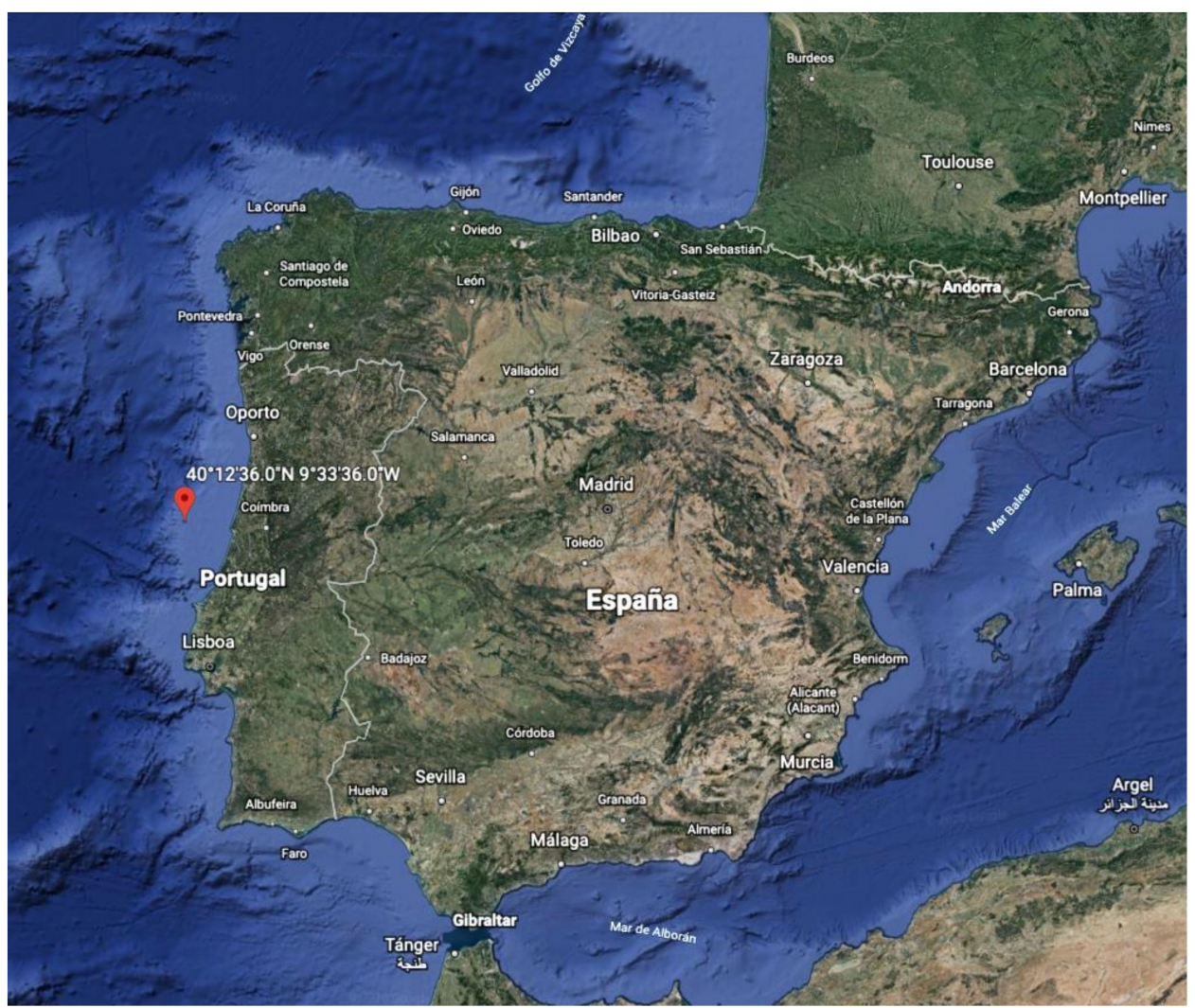

Figure 5. Case study Figueira da Foz (west coast of Portugal, Iberian Peninsula) [37]. 
The alternatives of the case of study depend on the electric tariff ( $50 € / \mathrm{MWh}$ or $150 € / \mathrm{MWh}$; $56.32 \$ / M W h$ or $168.97 \$ / M W h$ ) and the capital cost ( $6 \%$ and $8 \%$ ) (Table 3 shows the scenarios analysed). The total power of the farm is $500 \mathrm{MW}$.

Table 3. Scenarios analyzed for the SATH ${ }^{\circledR}$ platform.

\begin{tabular}{ccc}
\hline Scenario & Electric Tariff (E/MWh) & Capital Cost $\mathbf{( \% )}$ \\
\hline 1 & 50 & 6 \\
2 & 50 & 8 \\
3 & 150 & 6 \\
4 & 150 & 8 \\
\hline
\end{tabular}

\section{Results}

Regarding costs, results for a 500 MW floating offshore wind farm located in Figueira da Foz (Portugal) and composed of $50 \mathrm{SATH}^{\circledR}$ platforms are: $1.2 \%$ for the $C_{1}, 0.3 \%$ for the $C_{2}, 42.3 \%$ for the $C_{3}$, $2.9 \%$ for the $C_{4}, 51.5 \%$ for $C_{5}$ and $1.8 \%$ for $C_{6}$. Therefore, as Figure 6 is shown, the most significant costs of the $\mathrm{SATH}^{\circledR}$ platform are the manufacturing cost $(\mathrm{C} 3)$ and the exploitation cost (C5).

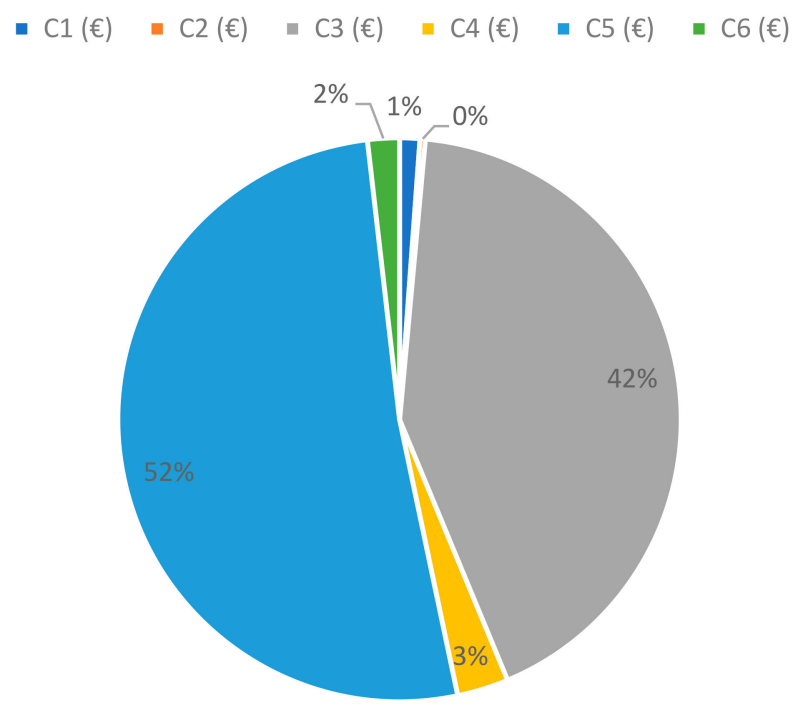

Figure 6. SATH ${ }^{\circledR}$ platform costs.

The total cost can be disaggregated in the sub-costs previously defined in the present paper, whose values are defined in Table 4 .

Regarding the economic parameters, Internal Rate of Return (IRR) of the project has a value of $0.12 \%$ in Scenarios 1 and 2 and $17.64 \%$ in Scenarios 3 and 4 . This is because the IRR does not depend on the capital cost of the project. In addition, the discounted pay-back period of the project is higher than 28 years for Scenarios 1 and 2 and 9 years for Scenarios 3 and 4. Accordingly, the project is not economically feasible for Scenarios 1 and 2 because IRR is lower than the capital cost considered and the number of years to recover the investment of the project is very high. This is because the electric tariff is very low. Alternatively, the project would be economically feasible for Scenarios 3 and 4 because the IRR is superior than the capital cost considered, and the payback period is low comparing it with the life of the project (20 years). In these last scenarios the electric tariff is high and this is the main reason why the project would be feasible. 
Table 4. Results of the sub-costs for the SATH ${ }^{\circledR}$ platform.

\begin{tabular}{|c|c|}
\hline Concept & Cost $(\%)$ \\
\hline $\mathrm{C}_{12}$-Legal aspects & $0.2 \%$ \\
\hline $\mathrm{C}_{13}$-Wind resource study, sea states study, seabed study & $1.0 \%$ \\
\hline $\mathrm{C}_{21}$-Special Purpose Vehicle (SPV) Cost & $0.3 \%$ \\
\hline $\mathrm{C}_{31}$-Generator manufacturing cost & $20.0 \%$ \\
\hline $\mathrm{C}_{32}$-Floating platform manufacturing cost & $11.4 \%$ \\
\hline $\mathrm{C}_{33}$-Mooring manufacturing cost & $5.8 \%$ \\
\hline $\mathrm{C}_{34}$-Anchoring manufacturing cost & $1.3 \%$ \\
\hline $\mathrm{C}_{35}$-Electric systems manufacturing cost & $3.8 \%$ \\
\hline $\mathrm{C}_{41}$-Generator installation cost & $0.2 \%$ \\
\hline $\mathrm{C}_{42}$-Floating platform installation cost & $1.1 \%$ \\
\hline $\mathrm{C}_{43}$-Mooring and anchoring installation cost & $0.9 \%$ \\
\hline $\mathrm{C}_{44}$-Electric systems installation cost & $0.8 \%$ \\
\hline $\mathrm{C}_{51}$ - Assurance cost & $0.0 \%$ \\
\hline $\mathrm{C}_{52}$-Administration and Operations cost & $1.9 \%$ \\
\hline $\mathrm{C}_{53}$-Maintenance cost & $16.4 \%$ \\
\hline $\mathrm{C}_{54}$-Onshore logistics & $0.6 \%$ \\
\hline $\mathrm{C}_{55}$-Offshore logistics & $32.1 \%$ \\
\hline $\mathrm{C}_{61}$-Generator dismantling cost & $0.9 \%$ \\
\hline $\mathrm{C}_{62}$-Mooring and anchoring dismantling cost & $0.8 \%$ \\
\hline $\mathrm{C}_{63}$-Electric system dismantling cost & $0.1 \%$ \\
\hline
\end{tabular}

Nevertheless, the Net Present Value (NPV) varies depending on the electric tariff and the capital cost taken into account. Results of the farm considered analyzing the SATH ${ }^{\circledR}$ platform are shown in Figure 7. Scenario 2 has the worst value for NPV (-531 M€), followed by Scenario 1 (-479 M€). However, Scenarios 3 and 4 have better values for NPV: $1657 \mathrm{M} €$ and $1365 \mathrm{M} €$, respectively. A project is economically feasible if its NPV is higher than zero. Therefore, regarding NPV Scenarios 1 and 2 are not economically feasible and Scenarios 3 and 4 are economically feasible because their value is higher than zero.

These steel structures make floating offshore wind energy more economically viable. If we compare the material costs of a steel platform with a concrete one, we find a reduction of $37 \%$ in the case of the concrete platform. These costs do not include the cost of installation, transportation, wind turbine or mooring lines. It is assumed that the costs of these elements that have not been included are similar for both cases according to [25,38]. 


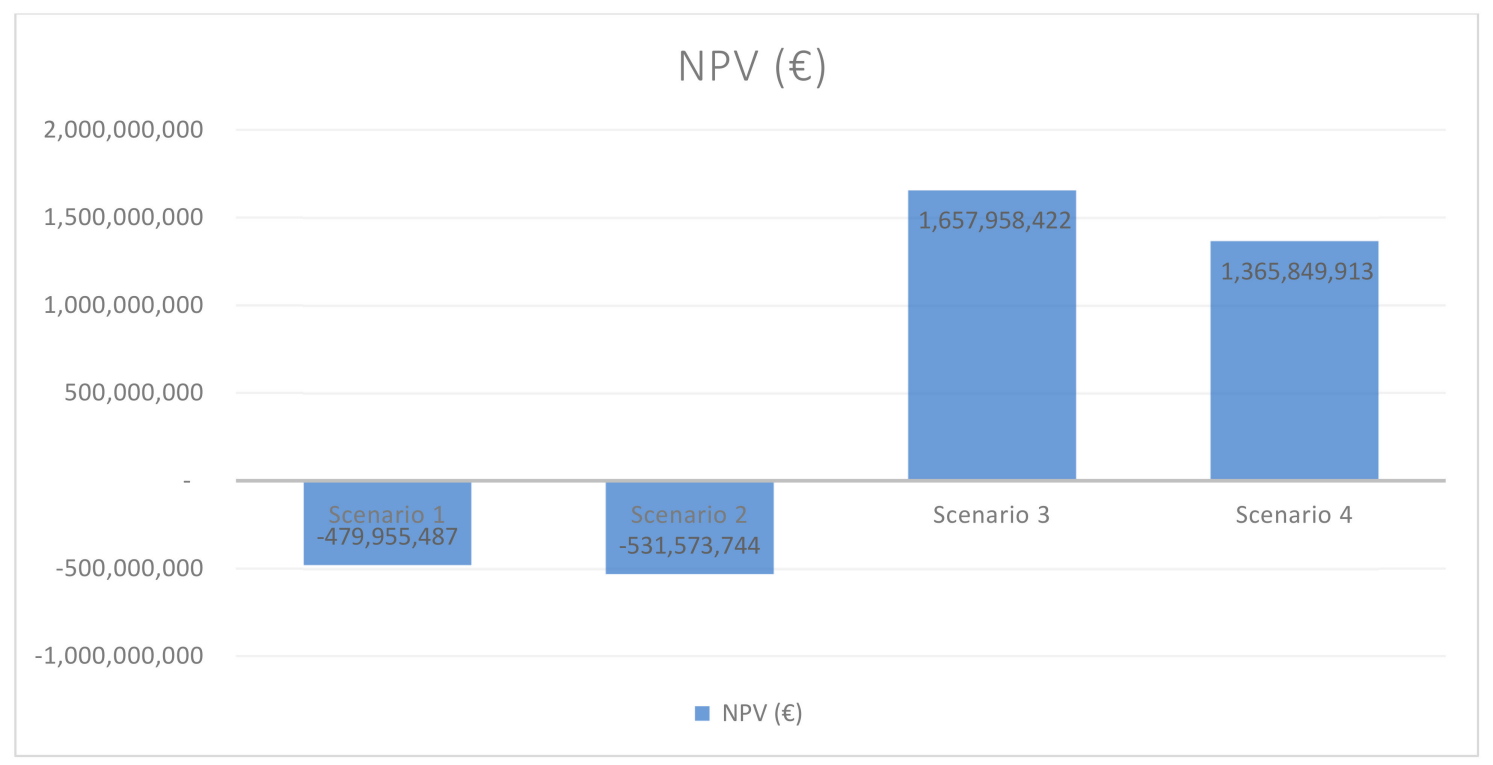

Figure 7. Net Present Value (NPV) for a farm with $S A T H^{\circledR}$ platforms.

\section{Conclusions}

The aim of this work is to develop an economic evaluation of an innovative floating offshore wind platform whose main material is concrete: The SATH ${ }^{\circledR}$ platform. The floating offshore wind platforms analyzed in previous studies consider concepts built on steel (for instance: WindFloat, TLP or Hywind platforms). However, concrete can have some advantages when comparing its properties with steel ones. These include the installation process, the absence of corrosion, easiness of building, etc. The SATH ${ }^{\circledR}$ platform has an easier way of installing comparing to other concrete platforms.

The paper developed a method to calculate the costs of the platform and the economic parameters to determine the economic feasibility of the farm. In order to determine the costs of the platform it is important to know its main components, which are different from the previous steel concepts: twin horizontal floaters stiffened with diaphragm walls with conical ends and linked with bar frames, lower tower section linked to floaters, pitch-roll plate linked to floaters and a single point mooring. In addition, considering the maintenance process, $\mathrm{SATH}{ }^{\circledR}$ platform can offer a significative advantage with respect to other floating solutions, or even to the fixed systems, in case of big repairs where singular maritime means such as jack-up rigs and floating cranes could be needed. In this context, SATH ${ }^{\circledR}$ platform can be easily disconnected and maintained. In addition, $\mathrm{SATH}^{\circledR}$ platform uses concrete, that is a material not requiring maintenance, in all parts of the platform in contact with sea water.

This case of study has analyzed a farm of 500 MW located in Figueira da Foz (Portugal) and with several alternatives depending on the electric tariff and the capital cost.

Results show if a farm of these characteristics is feasible in economic terms and which parameters its profitability depend on. Moreover, scenarios with higher electric tariff give better economic results for the same costs.

This paper is important in that it offers a new approach of the traditional floating offshore wind structures, which can represent a path towards the future of the floating offshore renewable energy technologies. The new concept analyzed in the paper, the concrete SATH ${ }^{\circledR}$ platform, can represent the future of the floating offshore wind sector if it achieves economic competitiveness in relation to the present steel floating platforms that are traditionally developed from concepts based in the fossil fuel sector. 
Author Contributions: Introduction: E.B.-S., D.C.-I., A.F.-V., À.M., I.L.-G., C.Á.-F., L.C., L.C.-S.; method: E.B.-S., D.C.-I., A.F.-V., L.C.-S.; case study: À.M., L.C.-S.; results: E.B.-S., D.C.-I., A.F.-V., À.M., I.L.-G., C.Á.-F., L.C., L.C.-S.; conclusions: D.C.-I., A.F.-V., L.C.-S.; supervision: L.C.-S.; preparation and scientific research: L.C.-S., A.F.-V., E.B.-S., D.C.-I. All authors have read and agreed to the published version of the manuscript.

Funding: This research was funded by EAPA_344/2016 ARCWIND project, co-financed by the European Regional Development Fund though the Interreg Atlantic Area Programme.

Acknowledgments: The authors would like to thank Saitec for the information provided.

Conflicts of Interest: The authors declare no conflict of interest.

\section{References}

1. Union, E. Acuerdo de París | Acción por el Clima. Available online: https://ec.europa.eu/clima/policies/ international/negotiations/paris_es (accessed on 31 July 2019).

2. Enkvist, P.A.; Nauclér, T.; Rosander, J. A cost curve for greenhouse gas reduction. McKinsey Q. 2007, 1, $34-45$.

3. Union, E. DIRECTIVE 2009/28/EC OF THE EUROPEAN PARLIAMENT AND OF THE COUNCIL of 23 April 2009 on the promotion of the use of energy from renewable sources and amending and subsequently repealing Directives 2001/77/EC and 2003/30/EC (Text with EEA relevance). Off. J. Eur. Union 2009, 5, 16-62.

4. Eurosat Statistics Explained, Estadísticas de Energía Renovable 2018. Available online: https://ec.europa.eu/ eurostat/statistics-explained/index.php/Main_Page (accessed on 12 March 2020).

5. Murdock, H.E.; Gibb, D.; André, T.; Appavou, F.; Brown, A.; Epp, B.; Sawin, J.L. Renewables 2019 Global Status Report; REN21: Paris, France, 2019.

6. Filgueira, A.; Seijo, M.A.; Muñoz, E.; Castro, L.; Piegari, L. Technical and Economic Study of Two Repowered Wind Farms in Bustelo and San Xoán, 24. 7 MW and 15. 84 MW respectively. In Proceedings of the 2009 International Conference on Clean Electrical Power, Capri, Italy, 9 June 2009; pp. 545-549.

7. Castro-Santos, L.; Vizoso, A.F.; Camacho, E.M.; Piegiari, L. Costs and feasibility of repowering wind farms. Energy Sources Part B Econ. Plan. Policy 2016. [CrossRef]

8. Castro-Santos, L.; Garcia, G.P.; Simões, T.; Estanqueiro, A. Planning of the installation of offshore renewable energies: A GIS approach of the Portuguese roadmap. Renew. Energy 2019, 132, 1251-1262. [CrossRef]

9. Kaldellis, J.K.; Zafirakis, D. The wind energy (r)evolution: A short review of a long history. Renew. Energy 2011, 36, 1887-1901. [CrossRef]

10. Zheng, C.W.; Li, C.Y.; Pan, J.; Liu, M.Y.; Xia, L.L. An overview of global ocean wind energy resource evaluations. Renew. Sustain. Energy Rev. 2016, 53, 1240-1251. [CrossRef]

11. Barthelmie, R.J.; Courtney, M.; Højstrup, J.; Sanderhoff, P. The Vindeby Project: A Description; DTU Library: Kongens Lyngby, Denmark, 1994.

12. DONG Energy. Available online: https://orsted.com/ (accessed on 12 March 2020).

13. GWEC I GLOBAL WIND REPORT 2018. Available online: https://gwec.net/global-wind-report-2018/ (accessed on 12 March 2020).

14. Plodpradit, P.; Dinh, V.N.; Kim, K.D. Coupled analysis of offshore wind turbine jacket structures with pile-soil-structure interaction using FAST v8 and X-SEA. Appl. Sci. 2019, 9, 1633. [CrossRef]

15. Yang, B.; Wei, K.; Yang, W.; Li, T.; Qin, B.; Ning, L. A feasibility study for using fishnet to protect offshore wind turbine monopile foundations from damage by scouring. Appl. Sci. 2019, 9, 5023. [CrossRef]

16. Shittu, A.A.; Mehmanparast, A.; Wang, L.; Salonitis, K.; Kolios, A. Comparative study of structural reliability assessment methods for offshore wind turbine jacket support structures. Appl. Sci. 2020, 10, 860. [CrossRef]

17. Sclavounos, P.D.; Lee, S.; DiPietro, J. Floating offshore wind turbines: Tension leg platform and taught leg buoy concepts supporting 3-5 mw wind turbines. In Proceedings of the European Wind Energy Conference (EWEC), Warsaw, Poland, 20-23 April 2010; pp. 1-7.

18. Castro-Santos, L.D.C.V. Cost Comparison of Three Floating Offshore Wind Platforms. J. Coast. Res. 2015, 31, 1217-1221. [CrossRef]

19. Counago, B.; Urbano, J.; Cerdán, L.M.; Urruchi, A.; Fernández, J.L.; Cortés, C.; Guanche, R. TELWIND- Integrated Telescopic tower combined with an evolved spar floating substructurefor low-cost deep water offshore wind and next generation of $10 \mathrm{MW}+$ wind turbines. 2016. Available online: https://pdfs.semanticscholar.org/0cbc/2a65975f115250b7256195d5d4955bb609eb.pdf?_ga=2. 222539474.832566553.1590488400-592356238.1574839601 (accessed on 1 March 2020). 
20. Saitec. Technical Documentation Floating Offshore Wind Turbine SATH-10 MW; Marine Operations: Bilbao Spain, 2019.

21. Marijuán, A.R. Offshore Floating Platforms. Analysis of a Solution for Motion Mitigation; Digitala Vetenskapliga Arkivet (DiVA): Stockholm, Sweden, 2017.

22. Jessen, K.; Laugesen, K.; Mortensen, S.M.; Jensen, J.K.; Soltani, M.N. Experimental Validation of Aero-Hydro-Servo-Elastic Models of a Scaled Floating Offshore Wind Turbine. Appl. Sci. 2019, 9, 1244. [CrossRef]

23. Rodriguez, J.C. Energía Eólica Offshore, Recubrimientos Basados en Nanopartículas para Aplicaciones Offshore. 2018. Available online: https://ingenieromarino.com/recubrimientos-basados-en-nanoparticulaspara-aplicaciones-offshore/ (accessed on 1 March 2020).

24. Borrell, C.M.I.; Hortigüela, A.C. WindCrete. Wind. Int. 2016, 12, 1-4.

25. Borrell, C.M.I.; Hortigüela, A.C.; Sandner, F.; Matha, D. Monolithic concrete off-shore floating sturcture for wind turbines. In Proceedings of the Annual Conference EWEA 2014 Annual Event: Conference Proceedings, Barcelona, Spain, 10-13 March 2014; pp. 107-111.

26. Baita-Saavedra, E.; Cordal-Iglesias, D.; Filgueira-Vizoso, A.; Castro-Santos, L. Economic aspects of a concrete floating offshore wind platform in the Atlantic Arc of Europe. Int. J. Environ. Res. Public Health 2019, 16, 4122. [CrossRef] [PubMed]

27. Saitec. Technical Documentation Floating Offshore Wind Turbine SATH-10 MW; O\&M Strategy and Accesibility: Barcelona, Spain; Bilbao, Spain, 2019.

28. Castro-Santos, L.; Diaz-Casas, V. Life-cycle cost analysis of floating offshore wind farms. Renew. Energy 2014, $66,41-48$.

29. Castro-Santos, L.; Filgueira-Vizoso, A.; Lamas-Galdo, I.; Carral-Couce, L. Methodology to calculate the installation costs of offshore wind farms located in deep waters. J. Clean. Prod. 2018. [CrossRef]

30. Carral-Couce, L.; Naya, S.; Alvarez Feal, C.; Lamas Pardo, M.; Tarrío-Saavedra, J. Estimating the traction factor and designing the deck gear for the anchor handling tug. Proc. Inst. Mech. Eng. Part M-J. Eng. Marit. Environ. 2017, 231, 600-615. [CrossRef]

31. SAITEC. Saitec Webpage. 2020. Available online: https://www.saitec.es/en/ (accessed on 1 February 2020).

32. Aubault, A.; Cermelli, C.; Roddier, D. Windfloat: A floating foundation for offshore wind turbines. Part III: Structural analysis. In Proceedings of the ASME 28th International Conference on Ocean, offshore and Arctic Engineering OMAE2009, Honolulu, HI, USA, 31 May-5 June 2009; pp. 1-8.

33. Driscoll, F.; Jonkman, J.; Robertson, A.; Sirnivas, S.; Skaare, B.; Nielsen, F.G. Validation of a FAST Model of the Statoil-hywind Demo Floating Wind Turbine. Energy Procedia 2016, 94, 3-19. [CrossRef]

34. Barrero, A. Saitec Elige la Costa Cántabra Para Ensayar su Plataforma eólica Flotante. 2019. Available online: https://www.energias-renovables.com/eolica/cantabria-albergara-en-sus-aguas-la-primera-20191125 (accessed on 1 February 2020).

35. Diaz, H.; Soares, C.G. Method for Multi-Criteria Choice of Wind Farm Location_IST Site Selection Report; IST: Lisbon, Portugal, 2019.

36. Díaz, H.; Soares, C.G. An integrated GIS approach for site selection of floating offshore wind farms in the Atlantic Continental European coastline. Renew. Sustain. Energy Rev. 2020. (Unpublished Paper).

37. Google Earth. Google Earth. 2020. Available online: https://www.google.com/earth/ (accessed on 1 February 2020).

38. Campos, A.; Molins, C.; Gironella, X.; Trubat, P. Spar concrete monolithic design for offshore wind turbines. In Proceedings of the Institution of Civil Engineers: Maritime Engineering; Thomas Telford Ltd.: London, UK, 2016; p. 15.

(C) 2020 by the authors. Licensee MDPI, Basel, Switzerland. This article is an open access article distributed under the terms and conditions of the Creative Commons Attribution (CC BY) license (http://creativecommons.org/licenses/by/4.0/). 